\title{
A Sensitive Phenol Electrochemical Sensor Based on Magnetic Oxide/Amino-Functional Graphene Nanocomposite
}

\author{
Zuchao Meng ${ }^{*}$, Mao Li, Chengxi Li, Xiang Liu, Zigang Lei \\ College of Chemistry and Chemical Engineering, Xi'an shiyou University, Xi'an Shaanxi 710065, \\ China \\ *E-mail: zcmeng@,xsyu.edu.cn
}

doi: $10.20964 / 2019.03 .25$

Received: 20 January 2018 / Accepted: 12 December 2018 / Published: 7 February 2019

\begin{abstract}
A sensitive electrochemical sensor for the detection of phenol was fabricated based on a magnetic oxide/amino-functionalized graphene $\left(\mathrm{Fe}_{3} \mathrm{O}_{4} / \mathrm{AGO}\right)$ nanocomposite. $\mathrm{Fe}_{3} \mathrm{O}_{4} / \mathrm{AGO}$ was synthesized by chemical coprecipitation. The morphologies and structures of $\mathrm{Fe}_{3} \mathrm{O}_{4} / \mathrm{AGO}$ were studied with a scanning electron microscope (SEM), transmission electron microscope (TEM), Fourier transform infrared spectroscope (FTIR) and X-ray diffractometer (XRD). The effects of the $\mathrm{pH}$ and scan rate on the electrocatalytical oxidation of phenol were also investigated. Under the optimized conditions, the oxidation peak currents were proportional to the phenol concentrations in the ranges of $0.45 \mu \mathrm{M} \sim 56 \mu \mathrm{M}$ and $156 \mu \mathrm{M} \sim 456 \mu \mathrm{M}$ with a lower detection limit of $0.4 \mu \mathrm{M}(S / N=3)$. Furthermore, the fabricated sensor was successfully applied to the detection of phenol in an oilfield wastewater sample with satisfactory results.
\end{abstract}

Keywords: $\mathrm{Fe}_{3} \mathrm{O}_{4}$ magnetic nanoparticle, amino-functional graphene, phenol, sensor

\section{$\underline{\text { FULL TEXT }}$}

(C) 2019 The Authors. Published by ESG (www.electrochemsci.org). This article is an open access article distributed under the terms and conditions of the Creative Commons Attribution license (http://creativecommons.org/licenses/by/4.0/). 